\title{
INVESTIGATION OF THE YIELD OF INDUSTRIAL TOMATO AFTER DIFFERENT FOLIAR TREATMENTS ON HUMUS SANDY SOIL
}

\author{
Attila Hüvely ${ }^{1^{*}}$, Judit Petö ${ }^{1}$, András Palkovics ${ }^{1}$ and Dávid Hegyesi ${ }^{2}$ \\ ${ }^{1}$ Department of Agricultural Science, Faculty of Horticulture and Rural Development, John von Neumann \\ University, Kecskemét, Hungary \\ ${ }^{2}$ Horticultural engineer BSc. student, Faculty of Horticulture and Rural Development, John von Neumann \\ University, Kecskemét, Hungary \\ https://doi.org/10.47833/2020.2.AGR.028
}

\begin{abstract}
Keywords:
tomato

humus sandy soil

organic manure

foliar fertilizer

tomato yield
\end{abstract}

\section{Article history:}

Received 4 May 2020

Revised 10 May 2020

Accepted 20 May 2020

\begin{abstract}
Our field experiment was made in 2019 in the study garden of the Faculty of Horticulture and Rural Development. The soil of the experiment was a slightly calcareous sand with a medium humus content and slightly alkaline. Three different foliar fertilizer treatments were applied on industrial tomato test plants, in parallel with the same soil base fertilization. The harvested yields were examined. Ripening accelerating compounds increased tomato yield. Potassium chloride treatment increased yield as well in 2019.
\end{abstract}

\section{Introduction}

Significant technological developments have been taken place in the last 10 years in the cultivation of industrial tomatoes in Hungary, mainly due to the increase in the capacity of the processing industry. The annual volume of domestic production exceeds 110,000 tons.

The development of technology primarily means a significant development of varieties, but there is also a significant innovation in the field of plant protection and nutrient supply. Perhaps the biggest break-through was achieved by the mechanization and increase in capacity of the harvest.

In our region, in Homokhátság, lying between the Danube and the Tisza rivers in the Great Plain, the cultivation conditions must be realized on soils with high quartz sand content, low humus content and lower productivity. We have to create growing circumstances, which can result approximately 100 t/ha tomato yield. The following factors should be focused on - in order of importance -, proper choice of the irrigable area, implementation of significant manure spreading (optimal doses are between 50-70 t/ha), selection of optimal variety, significant potassium base fertilization, significant nitrogen replenishment, in several smaller doses, after planting. Regular protection against weeds and leaf infections. Optimal, controlled irrigation, crop ripening control, mainly with foliar fertilizers, and optimal choice of harvest time [3, 4].

In order to increase the efficiency of fertilizers, it is now common to use complex, granular, coated, i.e. long-acting fertilizers containing individual concentrations of nutrients. Granulated organic fertilizers, which can be obtained generally, are concentrated, free of ammonia and weed seeds, are becoming more common. The supply of foliar fertilizers is now in very large. In the case of industrial tomatoes, the initial micronutrient deficiency and the subsequent (relative) calcium

\footnotetext{
* Corresponding author. Tel.: +36 517-661

E-mail address: huvely.attila@kvk.uni-neumann.hu
} 
deficiency can be prevented with foliar fertilizers, and from ripening the yield time and yield quality can be controlled by the agents applied through the foliage $[5,6,7,8]$.

The aim of our present study was to determine the effect of different ripening controlling foliar fertilizers on the yield of industrial tomato.

\section{Materials and methods}

Our experiment was carried out in the Faculty of Horticulture and Rural Development of John von Neumann University, in 2019.

The size of the area in the demonstration garden was 0.01 ha $(10 \times 10 \mathrm{~m})$. The soil of the experiment was a slightly calcareous $\left(2.52 \mathrm{~m} / \mathrm{m} \% \mathrm{CaCO}_{3}\right)$ sand with medium humus $(2.40 \mathrm{~m} / \mathrm{m} \%)$ content and slightly alkaline $\mathrm{pH}\left(7.39 \mathrm{pH}_{\mathrm{H} 2 \mathrm{O}}\right)$.

We made eight parallel rows. We used healthy seedlings being in good condition. Seedlings were planted in uniform spacing of $1.2 \times 0.25 \mathrm{~m}$.

Our test plant was H1281 hybrid tomato from Heinz Seed. It is an available hybrid currently that is well-proven in Hungarian growing. A short-growing, early-maturing variety.

It is a determined variety for processing. Fruits have $85-100 \mathrm{~g}$ average weight and thick walls, dark red color, high pigment content, and good (4,8 - 5.1) Brix\%.

According to the results of soil testing prior to planting, the soil nitrogen supply was medium, the phosphorus supply was very good and the potassium supply was in the medium range. According to the calculation of the MÉM-NAK fertilization advices further developed by our institution, the required amount of nutrients for the planned yield, in the whole growing season was $220 \mathrm{~kg} / \mathrm{ha}$ $\mathrm{N}, 80 \mathrm{~kg} / \mathrm{ha} \mathrm{P}_{2} \mathrm{O}_{5}, 300 \mathrm{~kg} / \mathrm{ha} \mathrm{K}_{2} \mathrm{O}[1,2]$. The listed amounts of the active ingredients were applied with organic fertilizer granules and complex K-overweight basic fertilizer before planting, and then after planting once with $\mathrm{N}$-overweight and twice with K-overweight complex fertilizer were applied. The amount of organic fertilizer granules per hectare was $2500 \mathrm{~kg}$, the total amount of complex fertilizers was $1190 \mathrm{~kg} / \mathrm{ha}$. The area has not received manure in the last 3 years.

During the plant care, foliar fertilizers containing urea and microelements were applied.

We examined the effect of various $\mathrm{KCl}$, Sweet and Ethrel solutions given by foliar feeding on tomato growing. Maturation controlling foliar fertilizers were applied in replicates, in two times, at 10 and $50 \%$ maturity, respectively.

The applied leaf nutrient treatments were the following:

- No. 1-2 rows: Control

- No. 3-4 rows: $\mathrm{KCl}, 40 \mathrm{~kg} / \mathrm{ha}$

- No. 5-6 rows: Ethrel, 0.2\%

- No. 7-8 rows: Sweet, $6.5 \mathrm{l} / \mathrm{ha}$.

The aim of the study was to determine the effect of the above foliar fertilizer treatments on the yield under the same soil fertilization conditions.

\section{Results}

The harvest was carried out on $15^{\text {th }}$ of August 2019. The picking was done by hand, but we followed the general method of machine picking, ie. only ripe berries of the appropriate color were collected and whole picking process took place once. The yields resulting after different treatments are shown in Figure 1. 


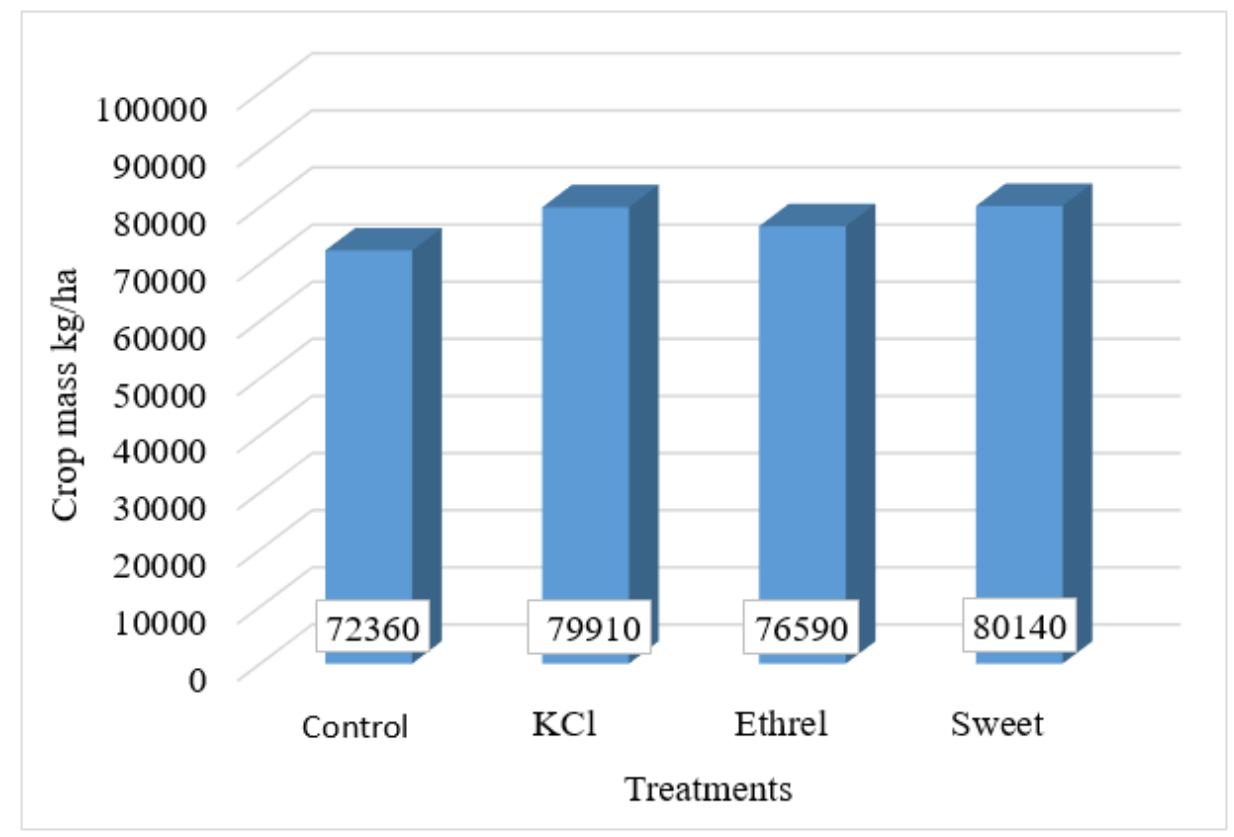

Figure 1. The effect of different treatments on yield of tomato.

The results showed that all the three foliar fertilizer types increased yields compared to the control treatment. The results of $\mathrm{KCl}$ and Sweet stimulator were almost the same, exceeding the control result by about $10 \%$. The variety in the experiment did not respond well to Ethrel treatment, and its vegetative parts, leaves, and entire stem system rapidly deteriorated, turned yellow, and withered as a result of the treatment. Due to the rapid degradation of the stem system, the ripe berries were quickly reached the soil surface here, which increased the occurrence of mass berry rot.

\section{Discussion}

The results of our study are worth examining them from two aspects. On the one hand, the results show that on sandy soils it is necessary to apply the amount of $200 \mathrm{~kg} / \mathrm{ha}$ of nitrogen active ingredient sometimes disputed by growers, and that the long-term, multi-year omission of high-dose organic fertilization can frustrate the achievement of a yield level of $100 \mathrm{t} / \mathrm{ha}$, even with the application of the most modern hybrids, fertilizer types, foliar fertilizers, regular irrigation and reasonable plant protection.

On the other hand, the importance of the maturation control agents used in practice is also supported by the results, supplemented by the fact that the typical dose of $15-20 \mathrm{~kg} / \mathrm{ha}$ of $\mathrm{KCl}$ foliar fertilizer can be increased in the practice in sand soils, the increase is approx. up to $40 \mathrm{~kg} / \mathrm{ha}$ enhances the beneficial effect of the agent.

\section{Acknowledgment}

Authors wish to thank for the support of the research carried out in the framework of the EFOP3.6.2-16-2017-00012 „Developing a functional, healthy and safe food product chain model from field to table in a thematic research network". The project is funded by the Hungarian State and the European Union, co-financed by the European Social Fund, and is part of the Széchenyi 2020 program. 


\section{References}

[1] BALÁZS S. (1985): Paradicsomtermesztés. Mezőgazdasági Kiadó, Budapest. pp. 63-91.

[2] BUZÁS I. (szerk.) (1983): A növénytáplálás zsebkönyve. Mezőgazdasági kiadó, Budapest. pp. 36-43.

[3] HARTZ, T.K.- JOHNSTONE, P.R.- FRANCIS, D.M.- MIYAO, E.M. (2005): Processing Tomato Yield and Friut Quality Improved with Potassium Fertigation. HortScience, Vol. 40 No.6. pp.1862-1867 DOI: 10.21273/ HORTSCI.40.6.1862.

[4] HORINKA T. (2010): Kertészeti növények komplett tápanyagellátása. Kertészek kis/Nagy Áruháza Kft. pp. 275-285.

[5] PREMSEKHAR, M.- RAJASHREE, V. (2009): Performance of hybrid tomato as influenced by foliar feeding of water soluble fertilizers. American-Eurasian Journal of Sustainable. Agriculture, p. 33.

[6] WOLDEMARIAM, S.H.- LAL, S.- ZELELEW, D.Z.- SOLOMON,- M.T. (2018): Effect of Potassium Levels on Productivity and Fruit Quality of Tomato. Journal of Agricultural Studies, Vol.6 No.1. DOI: 10.5296/jas.v6i1.12262.

[7] TERBE I.- SLEZÁK K.- KAPPEL N. (2011): Kertészeti és szántóföldi növények fejlődési rendellenességei. Mezőgazda Kiadó Budapest. pp. 121-126.

[8] HÜVELY, A. - PETÖ, J. - HEGYESI, D. (2019): The impact of different foliar fertilizers on the quantity and nutrient content of industrial tomato. Gradus Vol 6, No 3 (2019) pp. 219-226. 